\title{
WYBORY JAKO DEMOKRATYCZNY SPOSÓB KREOWANIA ORGANÓW WLADZY PUBLICZNEJ A DOBRO WSPÓLNE
}

W artykule poddano analizie problematykę kreowania w drodze wyborów organów władzy publicznej. Przedmiotem zainteresowania stały się tu zagadnienia dotyczace kreowania w powszechnych i demokratycznych wyborach takich organów państwowych, jak oba organy ustawodawcze, tj. Sejm i Senat, Prezydent Rzeczypospolitej, organy stanowiace samorządu terytorialnego oraz organ wykonawczy gminy. Dokonując analizy, uwagę poświęcono nie tyle szczegółowym zasadom wyboru tych organów, ile przede wszystkim wskazaniu zasad i standardów prawa wyborczego, które sa gwarancja demokratycznego charakteru wyborów oraz realizacji zasady suwerenności narodu w zgodzie i poszanowaniu z konstytucyjną zasadą dobra wspólnego.

I. Wolne wybory, przeprowadzane z poszanowaniem reguł pozwalających uczciwie uwzględnić wolę wyborców, są fundamentalnym składnikiem ustroju demokratycznego ${ }^{1}$. Wskazują na to różnego rodzaju definicje demokracji czy też ustroju demokratycznego, w których wybory - rozumiane jako sposób kreowania podmiotów władzy publicznej - sa obligatoryjnym i zwykle kluczowym ich elementem ${ }^{2}$. Dla przykładu Robert Dahl, analizując zasady funkcjonowania ustroju demokratycznego, wskazał szereg czynników go zabezpieczających. Są nimi m.in.: powszechne prawo udziału w wyborach; równe i uczciwe

${ }^{1}$ W. Łączkowski, Prawo wyborcze a ustrój demokratyczny, „Ruch Prawniczy, Ekonomiczny i Socjologiczny" 71, 2009, z. 2, s. 51.

${ }^{2}$ Pojęcie „demokracja” od swojego zarania budzi szereg dyskusji i kontrowersji. Brak także jednej, powszechnie akceptowalnej definicji tego terminu. Termin „demokracja” składa się z dwóch słów greckich: demos (lud) oraz kratos (władza). Stąd najczęściej demokrację definiuje się jako rządy ludu, sprawowane bezpośrednio lub też za pośrednictwem wybranych przez niego przedstawicieli. Zob. szerzej: G. Sartori, Teoria demokracji, tłum. P. Amsterdamski, D. Grinberg, Warszawa 1998; R.A. Dahl, Demokracja i jej krytycy, tłum. P. Amsterdamski, Warszawa 2012; idem, O demokracji, tłum. M. Król, Warszawa-Kraków 2000; Ch. Tilly, Demokracja, tłum. M. Szczubiałka, Warszawa 2008; G. Sørensen, Democracy and Democratization, Oxford 1993; A.H. Birch, The Concepts and Theories of Modern Democracy, London-New York 1993; R. Putnam, Demokracja w działaniu, tłum. J. Szacki, Kraków 1995; A. Lijphart, Democracy: Patterns of Majoritarian and Consensual Government in Twenty-One Countries, New Haven 1984. W polskiej literaturze przedmiotu zob. np. A. Antoszewski, Wspótczesne teorie demokracji, Warszawa 2016; M. Bankowicz, Demokracja: zasady, procedury, instytucje, Kraków 2006; A. Jamróz, Demokracja, Białystok 1999; S. Kowalczyk, U podstaw demokracji: zagadnienia aksjologiczne, Lublin 2001; M. Król, Jaka demokracja, Warszawa 2017; A. Zwoliński, Dylematy demokracji, Kraków 2010. 
wybory; swoboda rywalizacji o głosy wyborców; swobodny dostęp do biernego prawa wyborczego; swoboda zakładania i działania ugrupowań politycznych; swoboda ekspresji poglądów i ocen politycznych ${ }^{3}$. Z kolei Joseph Schumpeter twierdził, że systemy polityczne są demokracjami w takim stopniu, w jakim decydenci życia zbiorowego wybierani są w równych, uczciwych i okresowych wyborach, w trakcie których kandydaci swobodnie konkurują o głosy i w których ma prawo uczestniczyć cała dorosła ludność ${ }^{4}$. Tak zarysowane cechy determinuja z kolei istnienie wolności i praw politycznych, takich jak wolność słowa, wolność komunikowania się czy wolność zgromadzeń, koniecznych do przeprowadzenia konkurencyjnych i wolnych wyborów ${ }^{5}$. W podobnym duchu wyrażał się Charles Tilly. Stał on na stanowisku, że na demokrację musza składać się cztery obligatoryjne elementy: pluralistyczny system partyjny; powszechne prawo wyborcze; uczciwe, konkurencyjne i periodycznie przeprowadzane wybory oraz swoboda prowadzenia kampanii wyborczej i dostęp do mediów wszystkich sił politycznych ${ }^{6}$. Analizując przytoczone poglądy, z jednej strony można podnieść, że nadmierne kładzenie akcentu na wybory może zniekształcać definicję demokracji, na którą wszakże składa się dużo więcej elementów; z drugiej - nie ulega jednak wątpliwości, że procedury wyborcze odgrywają w demokracji kluczową i gwarancyjną rolę.

II. Jak słusznie podnosi się $\mathrm{w}$ doktrynie prawa, sama demokracja jest wielką wartością wówczas, gdy służy dobru wspólnemu ${ }^{7}$. Dlatego w rozważaniach dotyczących problematyki wyborów i prawa wyborczego w pierwszej kolejności należy zwrócić uwagę na treść zasady dobra wspólnego.

Warto w tym miejscu przypomnieć, że idea „dobra wspólnego” opiera się w Europie na dwóch filarach. Pierwszym z nich jest myśl republikańska ${ }^{8}$, której podstaw możemy doszukiwać się w dziełach Arystotelesa oraz Cycerona. W myśl tych rozważań państwo jest wspólnym dobrem wszystkich obywateli i pełni wobec nich służebną rolę. Do poglądów tych nawiązywał później także św. Tomasz z Akwinu, który uważał, że „dobro wspólne”, współistniejace $\mathrm{z}$ dobrem osobistym, miało stanowić cel polityki oraz cel prawa ${ }^{9}$. Poglądy Akwinaty wywarły wielki wpływ na nauczanie społeczne Kościoła katolickiego i interpretację w nim „dobra wspólnego”. Poglądy republikańskie reprezentował też renesansowy myśliciel Niccolò Machiavelli. Podchodził on jednak inaczej do rozumienia dobra wspólnego. Podczas gdy u Arystotelesa, Cycerona

\footnotetext{
${ }^{3}$ R.A. Dahl, Democracy in the United States: Promise and Performance, Chicago 1972, s. 38; idem, Polyarchy: Participation and Opposition, New Heven 1971, s. 34; idem, Demokracja..., s. 324-325.

${ }^{4}$ J. Schumpeter, Kapitalizm. Socjalizm. Demokracja, tłum. M. Rosiński, Warszawa 1995, s. $336-337$.

${ }^{5}$ Por. R.A. Dahl, Polyarchy..., s. 1-10.

${ }^{6}$ Ch. Tilly, Democracy, Cambridge 2007, s. 8.

${ }^{7}$ W. Łączkowski, op. cit., s. 52.

${ }^{8}$ H. Izdebski, Doktryny polityczno-prawne. Fundamenty wspótczesnych państw, Warszawa 2015 , s. 47.

${ }^{9}$ M. Mrozek, Dobro wspólne wczoraj i dziś. Na marginesie lektury Etyki nikomachejskiej i Summy Teologii, w: W. Arndt, F. Longchamps de Berier, K. Szczucki (red.), Dobro wspólne. Teoria i praktyka, Warszawa 2013, s. 75.
} 
i św. Tomasza było ono celem państwa służącym szczęściu obywateli, Machiavelli na pierwszym planie stawiał pomyślność samego państwa, jego suwerenność i interesy ${ }^{10}$.

Drugim filarem koncepcji dobra wspólnego jest niewątpliwie katolicka nauka społeczna. Podstawowych zrębów koncepcji dobra wspólnego należy poszukiwać w nauczaniu Jana XXIII ${ }^{11}$. Kościół katolicki, nie kwestionując roli instytucji państwa i stanowionego przez nie prawa, podkreśla wagę uwzględnienia porządku moralnego, a dobro wspólne traktuje jako element współzależny z dobrem osobistym ${ }^{12}$.

Na gruncie obu tych filarów ukształtowały się dwie tradycje postrzegania dobra wspólnego. Pierwsza klasyczna, zwana też personalistyczna, czerpiąca z dorobku myśli antycznej i katolickiej nauki społecznej, widzi dobro wspólne jako harmonię interesu publicznego $\mathrm{z}$ dobrem osobistym, kładzie jednak szczególny nacisk na troskę o jednostkę, jej wolności i prawa. Druga tradycja, zwana tradycją racji stanu, nawiązuje do myśli Machiavellego, na pierwszym planie w myśleniu o dobru wspólnym widzi państwo, jego interesy oraz rację stanu $^{13}$. Wskazane dwa sposoby postrzegania dobra wspólnego są widoczne także na gruncie polskiej doktryny prawa konstytucyjnego.

III. Zgodnie z art. 1 Konstytucji RP ${ }^{14}$ : „Rzeczpospolita Polska jest dobrem wspólnym wszystkich obywateli”. Tym samym ustrojodawca uznał pojęcie dobra wspólnego za konstytutywne dla państwa polskiego. Pomimo jednak tego, że „dobru wspólnemu” poświęcono dużo miejsca w literaturze prawniczej, jest ono pojęciem wieloznacznym o niezwykle trudnej do ustalenia treści normatywnej ${ }^{15}$. Z całą pewnościa jednak podniesienie „dobra wspólnego” do kategorii konstytucyjnej, uznawanej za jedną z podstawowych zasad ustroju Rzeczypospolitej ${ }^{16}$, pociaga za sobą różnego rodzaju konsekwencje prawne. Zgodzić się należy z wyrażanym w doktrynie prawa konstytucyjnego poglądem, że norma statuowana w art. 1 Konstytucji ma swoją autonomiczną treśćc ${ }^{17}$. Ustrojodaw-

${ }^{10}$ P. Słup, Dobro wspólne w Konstytucji III RP, „Zeszyt Studencki Kół Naukowych Wydziału Prawa i Administracji UAM" 2017, nr 7, s. 217.

${ }^{11}$ M. Piechowiak, Dobro wspólne jako fundament polskiego porzqdku konstytucyjnego, Warszawa 2012, s. 121.

${ }^{12}$ W. Łączkowski, Ekonomiczne i socjalne prawa człowieka a dobro wspólne, w: Godność cztowieka a prawa ekonomiczne $i$ socjalne. Ksiegga jubileuszowa wydana w piętnasta rocznice ustanowienia Rzecznika Praw Obywatelskich, Warszawa 2003, s. 38-39; B. Banaszak, Konstytucja Rzeczypospolitej Polskiej. Komentarz, wyd. 2, Warszawa 2012, s. 16-17.

${ }_{13}$ M. Piechowiak, Komentarz do art. 1 Konstytucji, w: M. Safjan, L. Bosek (red.), Konstytucja RP. Komentarz, t. 1: Art. 1-86, Warszawa 2016, s. 162.

${ }^{14}$ Konstytucja Rzeczypospolitej Polskiej z 2 kwietnia 1997 r., Dz. U. 1997, Nr 78, poz. 483 ze zm.

${ }_{15}$ Zob. A. Młynarska-Sobaczewska, Dobro wspólne jako kategoria normatywna, „Acta Universitatis Lodziensis. Folia Iuridica” 69, 2009 i cyt. tam literatura; eadem, Państwo jako dobro wspólne - czy obywatele musza być altruistami?, w: R. Balicki, M. Masternak-Kubiak (red.), W stużbie dobru wspólnemu. Ksiega jubileuszowa dedykowana Profesorowi Januszowi Trzcińskie$m u$, Warszawa 2012, s. 130 i n.

${ }^{16}$ Zob. K. Strzelczyk, Dobro wspólne jako naczelna zasada Konstytucji RP z dnia 2 kwietnia 1997 r., „Środkowoeuropejskie Studia Polityczne” 2009, nr 1-2.

${ }^{17}$ B. Banaszak, op. cit., s. 17. 
ca, wprowadzając do Konstytucji i bardzo eksponując zasadę dobra wspólnego, chciał przede wszystkim podkreślić służebną rolę państwa i jego organów wobec obywateli ${ }^{18}$. Państwo ma być środkiem służącym rozwojowi jednostek i tworzonych przez nie wspólnot. Innymi słowy, art. 1 Konstytucji określa, jakie ma być państwo, rozumiane jako wspólnota polityczna wszystkich obywateli, aby w pełni realizowało dobro członków tej wspólnoty ${ }^{19}$. Dobrem wspólnym nie jest więc samo państwo, ale państwo odpowiadające unormowanej w Konstytucji charakterystyce ustrojowej ${ }^{20}$, tj. oparte na rządach prawa, demokratycznym wyłanianiu władz publicznych, podziale władz oraz chroniące wolności i prawa człowieka i obywatela.

Janusz Trzciński, dokonujacc analizy pojęcia dobra wspólnego, zaproponował trzy płaszczyzny rozważań: wolności i prawa jednostki, wyboru optymalnego modelu instytucji publicznych oraz stanowienia prawa, będacego instrumentem realizacji wartości konstytucyjnych ${ }^{21}$. Korzystanie przez jednostkę z wolności i praw w obrębie koncepcji dobra wspólnego wyznacza szereg postanowień Konstytucji, które regulują m.in.: zasadę poszanowania godności człowieka (art. 30), wolności człowieka (art. 31), równości wobec prawa i w prawie (art. 32), sprawiedliwości społecznej (art. 2), solidaryzmu społecznego (wstęp do konstytucji), prawa do prywatności (art. 47, 49, 50 i 51), praw wyborczych (art. 62) czy też innych praw politycznych (art. 57, 58, 60 i 63). Wskazać należy także przepisy będące gwarancją korzystania z konstytucyjnych wolności i praw, tj. przede wszystkim: prawa do sadu (art. 45) oraz prawa do wniesienia skargi konstytucyjnej (art. 79). Jak się słusznie podnosi, konstytucyjne wolności i prawa mogą podlegać ograniczeniom, wśród których doszukać się można kryterium dobra wspólnego wyrażonego w sformułowaniu: „[...] gdy sa konieczne w demokratycznym państwie dla jego bezpieczeństwa lub porządku publicznego, bądź dla ochrony środowiska, zdrowia i moralności publicznej, albo wolności i praw innych osób" (art. 31 ust. 3) ${ }^{22}$. Przedstawiona konstrukcja sytuuje jednostkę przed państwem, choć jak wskazano, zasada ta nie ma charakteru bezwzględnego.

${ }^{18}$ W literaturze przedmiotu podkreśla się bardzo wyraźnie, że „dobro wspólne” określone w art. 1 Konstytucji, jest czymś zgoła innym niż państwo jako „wspólne dobro”, tj. terminem, którym posługiwała się Konstytucja z 1935 r. Szyk wyrazów, co wyraźnie zaznaczano w pracach nad Konstytucja, miał podkreślać indywidualistyczną koncepcję wolności i praw człowieka i obywatela w państwie oraz służebną rolę państwa wobec obywateli. Zob. W. Sokolewicz, M. Zubik, Komentarz do art. 1, w: L. Garlicki, M. Zubik (red.), Konstytucja Rzeczypospolitej Polskiej. Komentarz, t. 1, Warszawa 2016, s. 64-65; M. Piechowiak, Komentarz do art. 1..., s. 170-171.

19 B. Banaszak, op. cit., s. 16; M. Piechowiak, Komentarz do art. 1..., s. 174.

20 S. Gebethner, Rzeczpospolita $w$ świetle postanowień rozdziału pierwszego Konstytucji z 1997 roku, w: E. Zwierzchowski, M. Mączyński (red.), Podstawowe pojęcia pierwszego rozdziału Konstytucji Rzeczypospolitej Polskiej, Katowice 2000, s. 26; J. Trzciński, Rzeczpospolita Polska dobrem wspólnym wszystkich obywateli, w: J. Góral, R. Hauser, J. Trzciński (red.), Sadownictwo administracyjne gwarantem wolności i praw obywatelskich 1980-2005, Warszawa 2005, s. 460; M. Zubik, Refleksje nad „dobrem wspólnym” jako pojęciem konstytucyjnym, w: idem (red.), Prawo a polityka, Warszawa 2007, s. 398.

21 J. Trzciński, Rzeczpospolita Polska dobrem..., s. 455-456; idem, Rzeczpospolita jako dobro wspólne, „Rzeczpospolita” z 6 czerwca 2005 r., s. C3.

22 Idem, Rzeczpospolita jako..., s. C3. 
Drugi z wskazanych obszarów, dotyczący funkcjonowania instytucji publicznych, opiera się na założeniu, że organy państwa, realizując swoje zadania, mają określone obowiązki wobec jednostki, znajdujace podstawę w regulacji konstytucyjnej, a także wynikające z istoty państwa demokratycznego. Dodać należy, że obywatele, korzystając ze swoich wolności i praw, muszę mieć możliwość wpływania na wybór modelu instytucji publicznych oraz na ich bieżące funkcjonowanie (wybory, referendum).

Z kolei, trzeci obszar dotyczący stanowienia prawa jest dużo bardziej złożony. Prawo, aby mogło być uważane za element dobra wspólnego, musi spełniać określone kryteria. Przede wszystkim powinno być zgodne z Konstytucja, ze szczególnym poszanowaniem zarówno wolności i praw jednostki, jak i celów i zadań państwa. Gwarantem tej zasady powinien być niezależny sąd konstytucyjny. Społeczeństwo powinno mieć także wpływ na stanowienie prawa, i to nie tylko przez wybór w wyborach powszechnych organów ustawodawczych, lecz także przez prawo inicjatywy ustawodawczej, wysłuchań publicznych, konsultacji społecznych, a także transparentności procesu legislacyjnego oraz kontroli tego procesu przez niezależne media.

Podsumowując tę część rozważań, należy przyjać, że treści składających się na zasadę dobra wspólnego należy szukać w analizie przepisów konstytucji. Rzeczpospolita Polska jest bowiem dobrem wspólnym pozwalającym urzeczywistniać wolności i prawa jednostki, ale także państwem będącym dobrem wspólnym dla jego obywateli. Zasada wyrażona w art. 1 Konstytucji jest swego rodzaju imperatywem działania kategoriami dobra wspólnego i musi znajdować wyraz w postanowieniach ustawodawstwa zwykłego, jego interpretacji oraz w działalności wszelkich władz publicznych.

IV. W państwie demokratycznym wybory są nieodzowną instytucja życia publicznego, pozwalającą na wyłanianie przedstawicieli do organów państwowych. W ich wyniku dochodzi do realizacji zasady suwerenności narodu wyrażonej w art. 4 Konstytucji. Poddając analizie podstawowe zasady prawa wyborczego i starajac się wskazać na standardy tego prawa wyznaczane przez zasadę dobra wspólnego, można powrócić do zaproponowanych przez J. Trzcińskiego trzech płaszczyzn rozważań o dobru wspólnym. Zatem na gruncie problematyki wyborczej będą nimi: prawa wyborcze obywateli i sposób ich realizacji, wybór optymalnego modelu instytucjonalnego systemu wyborczego i procesu wyborczego, w tym instytucji wyborczych oraz stanowienie prawa wyborczego. Zaproponowany podział nie wyczerpuje oczywiście całokształtu problematyki prawa wyborczego, ale pozwala na sformułowanie najważniejszych jego standardów z punktu widzenia realizacji zasady dobra wspólnego.

Prawa wyborcze sa jednymi z najważniejszych praw politycznych obywatela, gdyż dotyczą jego wpływu na kształt i skład personalny organów publicznych pochodzaccych z wyborów. Trybunał Konstytucyjny w wyroku z 10 listopada 1998 r., wypowiadajac się w sprawie rangi praw wyborczych, podniósł: „że w demokratycznym państwie prawnym prawa wyborcze należą do fundamentalnych praw politycznych i dlatego każde ich ograniczenie poddane jest szczególnie ostremu reżimowi prawnemu. Prawa wyborcze przysługują w zasadzie wszystkim dorosłym obywatelom, zdolnym do zajmowania się swoimi 
własnymi sprawami, zaś ograniczenie tych praw jest dopuszczalne wyłącznie wtedy, gdy ustawa zasadnicza wyraźnie to przewiduje, przy czym przepisy konstytucyjne ustanawiajace ograniczenia - jako przepisy wprowadzające wyjątki od ogólnej reguły - podlegają zawsze ścisłej, literalnej wykładni”23.

Prawo wybierania (czynne prawo wyborcze) jest podmiotowym prawem każdego obywatela. Należy do praw człowieka w szerokim znaczeniu i znajduje się pod ochroną przepisów konstytucji i prawa międzynarodowego. Z prawa tego wynikaja określone uprawnienia dla objętych nim osób oraz związane z nim określone obowiązki władz publicznych. Najważniejszy z nich to zapewnienie warunków swobodnego realizowania prawa na jednakowych zasadach przez wszystkich uprawnionych. W systemie praw człowieka prawo wybierania jest ujmowane jako samoistne prawo podmiotowe, będące konkretyzacja prawa do uczestniczenia w rządzeniu państwem.

Prawo wybierania jest uprawnieniem, z którego obywatel może skorzystać lub nie. Jednakże analizując to praw z punktu widzenia realizacji dobra wspólnego, należy stwierdzić, że prawo wyborcze powinno być tak konstruowane i przewidywać takie instytucje i formy głosowania, aby stwarzać wyborcom jak największe możliwości udziału w wyborach celem wyboru przedstawicieli, którzy w ich imieniu będą sprawować władzę. Ustawodawca nie może ograniczać różnych form wyrażenia woli przez obywatela w procesie wyborczym, zakładając a priori, że będą one nadużywane. To po stronie państwa leży obowiązek, aby z jednej strony zapewnić jak najszerszą możliwość udziału w akcie głosowania, a z drugiej - nie dopuścić do jakichkolwiek nadużyć, które zachwiałyby zaufaniem do procesu wyborczego. Prawo wyborcze służy nie tylko wyłonieniu przedstawicieli Narodu, ale także - co jest równie ważne - musi mieć charakter gwarancyjny i stwarzać możliwości realizacji praw wyborczych ${ }^{24}$. Jak zauważył TK w wyroku z dnia 20 lipca 2011 r.: „prawodawca powinien tworzyć prawo wyborcze sprzyjające powszechnej, równej i bezpośredniej partycypacji obywateli w życiu publicznym. Jest ona wskaźnikiem poczucia odpowiedzialności obywateli za losy Ojczyzny. Warto zauważyć, że wśród przymiotników wyborczych ustrojodawca na pierwszym miejscu zawsze wymienia, iż wybory są powszechne, co prowadzi do wniosku, że powszechny udział obywateli w wyborach stanowi samoistną wartość konstytucyjną"25.

Drugim elementem składającym się na podmiotowe prawa wyborcze jest prawo do kandydowania (bierne prawo wyborcze) ${ }^{26}$. Według TK bierne prawo wyborcze obejmuje nie tylko uprawnienie do ubiegania się o mandat, lecz także prawo do objęcia i wykonywania go, jeśli został uzyskany w wyniku niewadliwie przeprowadzonych wyborach ${ }^{27}$. Konstytucja wprost stwarza gwarancję realizacji prawa do kandydowania w art. 99 (wybory do Sejmu i do Senatu) oraz w art. 127 ust. 2 i 3 (wybory prezydenta). Inaczej sytuacja wygląda

${ }^{23}$ Wyrok TK z 10 listopada 1998 r., K 39/97.

24 Zob.: wyrok TK z 20 lipca 2011 r., K 9/11.

25 Ibidem.

26 A. Sokala, Bierne prawo wyborcze, w: idem, B. Michalak, P. Uziębło, Leksykon prawa wyborczego i referendalnego oraz systemów wyborczych, Warszawa 2013, s. 23.

27 Zob. wyroki TK z: 13 marca 2007 r., K 8/07; 11 maja 2007 r., K 2/07; 24 listopada 2008 r., K 66/07. 
w przypadku wyborów do organów stanowiących samorządu terytorialnego oraz wyborów wójtów, burmistrzów i prezydentów. Czynne prawo wyborcze do organów samorządu terytorialnego zagwarantowane zostało w art. 62 ust. 1 Konstytucji. Nie ma natomiast w niej przepisu, który wprost reguluje bierne prawo wyborcze w odniesieniu do wyborów samorządowych. Można jednak takie prawo wywodzić z art. 60 Konstytucji, który stanowi, że „Obywatele polscy korzystający z pełni praw publicznych maja prawo dostępu do służby publicznej na jednakowych zasadach”. W świetle tej regulacji jedyna przesłanka jest pełnia praw publicznych, a korzystanie z tego prawa musi się odbywać na jednakowych zasadach. Jeszcze dalej w gwarancjach dotyczacych prawa do kandydowania w wyborach samorządowych poszedł TK, który w wyroku z 6 kwietnia 2016 r. stwierdził, że należy rozszerzyć na bierne prawo wyborcze regulacje gwarancyjna $\mathrm{z}$ art. 62 ust. 1 Konstytucji, gdyż przemawia za tym to, że skoro podstawowym warunkiem korzystania z biernego prawa wyborczego jest posiadanie prawa czynnego, to wspomniany art. 62 ust. 1 Konstytucji de facto odnosi się do prawa kandydowania w wyborach samorządowych ${ }^{28}$. Przyznając słuszność takiemu stanowisku, należy przypomnieć, że wszelkie ograniczenia praw wyborczych, także prawa do kandydowania, musza mieć wyraźna podstawę w Konstytucji ${ }^{29}$. Jest to daleko idące ograniczenie swobody ustawodawcy w kształtowaniu zasad prawa do kandydowania. Z tego punktu widzenia, wprowadzenie ograniczenia do dwóch liczby kadencji wójtów, burmistrzów lub prezydentów narusza istotę prawa do kandydowania i budzi wątpliwości co do zgodności z Konstytucją ${ }^{30}$. Z punktu widzenia realizacji zasady dobra wspólnego prawa wyborcze w państwie demokratycznym maja charakter fundamentalny. Ich ograniczanie zawsze musi mieć charakter nadzwyczajny, być uzasadnione właśnie realizacją dobra wspólnego i znajdować wyraźna podstawę w przepisach konstytucyjnych ${ }^{31}$.

Realizację dobra wspólnego wiązać należy także z upodmiotowieniem obywateli jako zgłaszajacych kandydatów wyborach. Postanowienia takie odnajdziemy w art. 100 ust. 1 (wybory do Sejmu i do Senatu) oraz w art. 127 ust. 3 Konstytucji (wybory prezydenta). Zgodnie z tymi regulacjami kandydatów zgłaszają wyborcy, jak również mogą zgłaszać, a w przypadku wyborów do parlamentu - także partie polityczne. Konstytucja pomija jednak całkowicie tę problematykę w odniesieniu do wyborów samorządowych. Należy jednak przyjąć, że dla pełnej realizacji zasady dobra wspólnego w demokratycznym państwie prawnym co do zasady wybory do organów centralnych samorządo-

28 Zob. wyrok TK z 6 kwietnia 2016 r., P 5/14.

${ }^{29}$ Wyrok TK z 10 listopada 1998 r., K 39/97.

30 Regulację taka zawiera art. 11 § Kodeksu wyborczego znowelizowany ustawą z 11 stycznia 2018 r. o zmianie niektórych ustaw w celu zwiększenia udziału obywateli w procesie wybierania, funkcjonowania i kontrolowania niektórych organów publicznych (Dz. U. 2018, poz. 130).

${ }^{31} \mathrm{Z}$ taka sytuacją mieliśmy do czynienia, gdy do polskiego prawa wyborczego wprowadzano tzw. przesłankę niekaralności, tj. pozbawienia w wyborach do Sejmu i do Senatu biernego prawa wyborczego osoby skazane prawomocnym wyrokiem na karę pozbawienia wolności za przestępstwo umyślne ścigane z oskarżenia publicznego. Ustawowe ograniczanie prawa do kandydowania - które dotyka istoty tego prawa - było niewystarczajace i wymagało interwencji ustawodawcy konstytucyjnego. Zob.: ustawa z 7 maja 2009 r. o zmianie Konstytucji (Dz. U. 2009, Nr 114, poz. 946). 
wych powinny się opierać na takich samych zasadach o charakterze podstawowym. Pomocna w ustaleniach może być także zasada pomocniczości. Wynika z niej bowiem konieczność szczególnej troski o funkcjonowanie mechanizmów demokratycznych $\mathrm{w}$ wyborach samorządowych, zatem także o zapewnienie szczególnych praw członkom wspólnot samorządowych jako wyborcom ${ }^{32}$.

V. Rozważając problematykę standardów modelu instytucjonalnego systemu wyborczego i procesu wyborczego, w pierwszej kolejności należy wskazać na sposób ukształtowania administracji wyborczej. W Polsce po 1989 r. ukształtował się sędziowski model administracji wyborczej ${ }^{33}$. Dość zgodnie przyjmowano, że udział w organach wyborczych przedstawicieli władzy sądowniczej (będącej zgodnie z art. 173 Konstytucji władzą odrębną i niezależną od innych władz) oraz niezależność, niezawisłość oraz apolityczność sędziowska będa gwarancja obiektywizmu, nieulegania naciskom politycznym, uczciwego przeprowadzenia całej procedury wyborczej, a przede wszystkim rzetelnego ustalenia wyników wyborów ${ }^{34}$. Funkcjonujący model administracji wyborczej spotykał się także $\mathrm{z}$ bardzo pozytywną oceną $\mathrm{w}$ literaturze przedmiotu ${ }^{35}$ oraz badaniach opinii publicznej ${ }^{36}$. Wydawało się, że przyjęty w Polsce model sędziowski był objęty konsensem głównych sił politycznych. Przyjmowano, że związane z nim cechy niezależności i apolityczności sa gwarancją profesjonalnego, obiektywnego i uczciwego prowadzenia procesu wyborczego, co z kolei jest wyrazem realizacji zasady dobra wspólnego.

Niestety Państwowa Komisja Wyborcza (PKW) nie posiada umocowania w Konstytucji ${ }^{37}$, a co za tym idzie - nie posiada gwarancji przed ingerencja ustawodawcy w jej niezależny i apolityczny charakter. Na mocy nowelizacji Kodeksu wyborczego ze stycznia 2018 r. ${ }^{38}$ zmieniono kształt osobowy PKW.

${ }^{32}$ H. Izdebski, Limitowanie kadencji władz publicznych w świetle Konstytucji RP, <http:// www.metropolie.pl/wp-content/uploads/2017/03/H.Izdebski-LIMITOWANIE-KADENCJI-W\%C5\%81ADZ-PUBLICZNYCH-W-SWIETLE-KONSTYTUCJI-RP.pdf> [dostęp: 5.01.2018].

${ }^{33} \mathrm{Na}$ temat modeli administracji wyborczej zob. szerzej: D. Sześciło, Modele administracji wyborczej w wybranych państwach, „Studia Wyborcze” 15, 2013.

${ }^{34}$ F. Rymarz, Udziat sędziów w organach wyborczych, w: idem (red.), 10 lat demokratycznego prawa wyborczego Rzeczypospolitej Polskiej (1990-2000), Warszawa 2000, s. 44.

${ }^{35}$ S. Gebethner, Wybory do Sejmu $i$ do Senatu. Komentarz do Ustawy z dnia 12 kwietnia 2001 r. - Ordynacja wyborcza do Sejmu Rzeczypospolitej Polskiej i do Senatu Rzeczypospolitej Polskiej, Warszawa 2001, s. 50; A. Sokala, M. Święcki, Administracja wyborcza w III Rzeczypospolitej Polskiej (struktura organizacyjna i charakter prawny), w: F. Rymarz (red.), Iudices electionis custodes (Sędziowie kustoszami wyborów), Warszawa 2007, s. 172; A. Żukowski, System wyborczy do Sejmu i Senatu RP, Warszawa 2004, s. 77-80; A. Kisielewicz, Komentarz do art. 157, w: K.W. Czaplicki et al., Kodeks wyborczy. Komentarz, Warszawa 2014, s. 380.

${ }^{36}$ Wyniki badań dotyczące zaufania do organów wyborczych przytacza A. Sokala, Kontrowersje wokót kształtu polskiej administracji wyborczej, „Studia Wyborcze” 18, 2014, s. 18-19.

${ }^{37}$ Zob. F. Rymarz, Konstytucjonalizacja Państwowej Komisji Wyborczej (wnioski de lege ferenda), w: idem (red.), Demokratyczne standardy prawa wyborczego Rzeczypospolitej Polskiej. Teoria i praktyka, Warszawa 2005, s. 239 i n.; B. Michalak, Kierunki reformy systemu wyborczego na tle praktyki wyborczej w Polsce. Wybrane aspekty, „Athenaeum” 21, 2009, s. 168 i n.

${ }^{38}$ Ustawa z 11 stycznia 2018 r. o zmianach niektórych ustaw w celu zwiększenia udziału obywateli w procesie wybierania, funkcjonowania i kontrolowania niektórych organów publicznych (Dz. U. 2018, poz. 130). 
Dotychczasowy model niezależnego organu wyborczego opartego na sędziach najważniejszych organów władzy sądowniczej ${ }^{39}$ zostanie zastapiony przez skład w przeważajaccym mierze polityczny. Zgodnie z nową treścią art. 157 $\S 2$ Kodeksu w skład PKW ma wchodzić po jednym sędzim TK i NSA, wskazanym przez prezesów tych organów (wybieranych na dziewięcioletnią kadencję), a także 7 osób posiadajacych kwalifikacje do zajmowania stanowiska sędziego wskazanych przez Sejm (na okres kadencji Sejmu). Warto podkreślić, że osoby te nie będą sędziami, a muszą jedynie legitymować się kwalifikacjami do zajmowania stanowiska sędziego ${ }^{40}$. W efekcie najważniejszy organ wyborczy będzie w zdecydowanej większości pochodził z nadania politycznego. Nominacja polityczna do PKW może powodować, że organ ten nie będzie wolny od partyjnych nacisków, co z kolei może podważać zaufanie do całego procesu wyborczego. Duże wątpliwości budzi także możliwość odwołania członka PKW przez prezydenta na wniosek podmiotu wskazującego. W efekcie istnieje zagrożenie, że większość parlamentarna będzie mogła usuwać ze składu PKW osoby, które z różnych przyczyn będą dla niej niewygodne ${ }^{41}$. Obecny skład PKW zakończy swoja działalność z pierwszym dniem kadencji Sejmu wybranego w 2019 r. W efekcie nie pozwoli to PKW skutecznie dokończyć całej procedury weryfikacji poprawności przeprowadzenia tych wyborów, przede wszystkim weryfikacji poprawności złożonych sprawozdań finansowych przez komitety wyborcze. Przyjęta regulacja w tym zakresie budzi poważne wątpliwości z perspektywy jej zgodności z zasada demokratycznego państwa prawnego ${ }^{42}$. Reforma dotknie także komisarzy wyborczych. Nie będą oni jak dotychczas sędziami, tylko urzędnikami powoływanymi przez PKW na wniosek ministra spraw wewnętrznych, spośród osób mających wykształcenie prawnicze. Dotychczasowy system sędziowski gwarantował przejrzystość i uczciwość wyborów. W nowej formule istnieje zagrożenie, że komisarze wyborczy moga być byłymi członkami lub współpracownikami partii politycznych. Przyjęte rozwiązanie należy ocenić negatywnie jako niebezpieczne dla bezstronności procesu wyborczego

$\mathrm{W}$ analizie modelu instytucjonalnego systemu wyborczego i procesu wyborczego z perspektywy dobra wspólnego warto zwrócić uwagę na podstawowe cele wyborów. W przede wszystkim należy wskazać, że „prawo wyborcze powinno gwarantować, że wynik wyborów będzie w możliwie największym

${ }^{39} \mathrm{~W}$ skład PKW dotychczas wchodziło 9 sędziów: 3 wskazanych przez Prezesa Trybunału Konstytucyjnego, 3 wskazanych przez Pierwszego Prezesa Sądu Najwyższego oraz 3 wskazanych przez Prezesa Naczelnego Sądu Administracyjnego. Zob. art. 157 § 2 Kodeksu wyborczego.

${ }^{40}$ Zgodnie z art. 61 ustawy z 27 lipca 2001 r. - Prawo o ustroju sądów powszechnych moga być to m.in.: prokuratorzy, osoby wykonujące przez co najmniej 3 lata zawód adwokata, radcy prawnego lub notariusza, profesorowie i doktorzy habilitowani nauk prawnych oraz osoby, które przez co najmniej 3 lata zajmowały stanowisko radcy Prokuratorii Generalnej Rzeczpospolitej Polskiej.

41 P. Uziębło, Opinia prawna w sprawie zmian w kodeksie wyborczym wprowadzonych ustawą z 14 grudnia 2017 r., Warszawa styczeń 2018, s. 4, <http://www.batory.org.pl/upload/files/Programy\%20operacyjne/Masz\%20Glos/Opinia\%20prawna\%20w\%20sprawie\%20zmian\%20w\%20 kodeksie\%20wyborczym\%20wprowadzanych\%20ustawa $\% 20$ z $\% 20$ dnia $\% 2014 \% 20$ grudnia $\% 20$ 2017 r.pdf> [dostęp: 15.01.2018].

42 Ibidem, s. 4. 
stopniu urzeczywistniał wolę Narodu. Z jednej strony oznacza to konieczność skonstruowania systemu wyborczego w taki sposób, by odzwierciedlał rzeczywiste poparcie udzielone poszczególnym kandydatom ubiegającym się o wybór do organów przedstawicielskich” (idea wyborów sprawiedliwych) ${ }^{43}$. Z drugiej jednak - prawo wyborcze „musi być tak skonstruowane, by pozwalało na wyłonienie władzy stabilnej i skutecznej (idea wyborów skutecznych). Znalezienie odpowiedniego systemu wyborczego, który zapewni osiagnięcie tego celu, niejednokrotnie wymaga ważenia różnych wartości konstytucyjnych, które nie mogą być równocześnie realizowane w maksymalnym stopniu ${ }^{44}$, tak aby zachować balans między ideą „wyborów sprawiedliwych”, wynikającą z zasady równości wyborów, a ideą „wyborów skutecznych”, pozwalającą na wyłonienie w wyborach stabilnej i skutecznej władzy ${ }^{45}$.

W przypadku wyborów do Sejmu ustawodawca przy konstruowaniu systemu wyborczego jest związany konstytucyjną zasadą proporcjonalności. Zasada ta charakteryzuje się jednak dużym stopniem ogólności. Konstytucjonalizacja omawianej zasady bez jej uszczegółowienia powoduje, że ustawodawca posiada relatywnie dużą swobodę w kształtowaniu poszczególnych elementów systemu wyborczego. Zmieniajac pewne elementy systemu wyborczego, takie jak: struktura okręgów wyborczych, formuła alokacji mandatów czy progi zaporowe, może znacząco wpływać na wynik wyborów ${ }^{46}$.

Dla zgodności z zasadą dobra wspólnego system wyborczy musi spełniać wszystkie standardy respektowane w państwie demokratycznym. Wiąże się to z respektowaniem zasady wolnych wyborów, która umożliwia wyborcom nieskrępowany udział w wyborach, zgłaszania kandydatów, swobody kształtowania programów wyborczych i ich rozpowszechniania, nieskrępowanego prowadzenia agitacji wyborczej, oraz swobody podejmowania decyzji wyborczych ${ }^{47}$. W wyroku z 21 lipca 2009 r. TK stwierdził, że zasadniczymi elementami zasady wolności wyborów sa ,autentyczna wolność wypowiedzi i zgromadzeń, ład medialny w państwie w ogóle, dostępność do lokalnego rynku medialnego, przejrzyste procedury pozyskiwania niezbędnych środków finansowych na prowadzenie kampanii, odpowiednie rzeczywiste gwarancje ochrony praw wyborczych”. Trybunał zaznaczył też, że ,jednym z najważniejszych elementów wolnych wyborów jest wolna debata publiczna prowadzona podczas kampanii wyborczej przez wszystkich zainteresowanych obywateli”48.

Wskazując na standardy prawa wyborczego realizujace zasadę dobra wspólnego, należy poświęcić osobne miejsce zasadzie równości. Stanowi ona jeden z fundamentów demokratycznych wyborów. Jest ona równocześnie zasadniczym elementem wolnych wyborów oraz odzwierciedleniem ogólnej zasady równości każdego człowieka wobec prawa. Słusznie uważa się, że obok

${ }^{43}$ Zob. wyrok TK z 3 listopada 2006 r., K 31/06.

44 Ibidem.

${ }^{45}$ K. Urbaniak, Konstytucyjna zasada proporcjonalności wyborów i jej implementacja w prawie wyborczym do Sejmu RP, w: S. Patyra, M. Sadowski, K. Urbaniak (red.), Konstytucja $w$ państwie demokratycznym, Poznań 2017, s. 232.

46 Ibidem, s. 241.

47 Zob. wyrok TK z 20 lipca 2011 r., K 9/11.

48 Zob. wyrok TK z 21 lipca 2009 r., K 7/09. 
zasady powszechności wyborów jest ona najważniejszą z zasad dotycząca korzystania z praw politycznych ${ }^{49}$. Zasada równości wyborów oznacza, że prawo wyborcze powinno stwarzać jednakowe gwarancje prawne dla wszystkich bioracych udział w wyborach ${ }^{50}$. W doktrynie prawa konstytucyjnego nie ma zgody co do rozumienia zasady równości wyborów ${ }^{51}$. Część przedstawicieli doktryny dostrzega jedynie dwa aspekty owej zasady, czyli równość formalną i materialną. Zwolennicy innego poglądu wskazują dodatkowo na trzeci aspekt - mianowicie równość szans wyborczych podmiotów bioracych udział w procesie wyborczym (zasada wyborczego fair play). Co do zasady panuje zgoda wśród przedstawicieli doktryny prawa, co do znaczenia aspektu formalnego i materialnego równości wyborów. Równość formalną widzą oni jako przydzielenie każdemu wyborcy jednego (one man - one vote) lub takiej samej liczby głosów ${ }^{52}$. Pamiętać jednak należy, że elementem formalnego aspektu zasady równości jest także zapewnienia możliwości uczestniczenia w wyborach na jednakowych zasadach osobom korzystającym z prawa do głosowania (rejestry wyborcze, ważność głosu) ${ }^{53}$.

Konstytucja nie wprowadziła zasady równości jako standardu obowiązującego we wszystkich wyborach odbywajacych się w Polsce. Zasadę, że wybory mają mieć charakter równy, odnajdujemy w normach rangi konstytucyjnej w przypadku wyborów do Sejmu (art. 96 ust. 2 Konstytucji), wyborów prezydenckich (art. 127 ust. 1 Konstytucji) oraz wyborów samorządowych (art. 169 ust. 2 Konstytucji). Zasadę tę pominięto w przypadku wyborów do Senatu

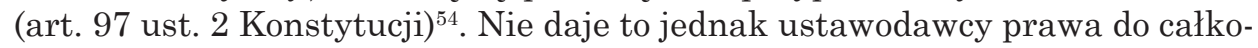
witego pominięcia w wyborach do Senatu zasady równości. Należy podkreślić, że rozwiązania przyjęte przez prawo wyborcze w zakresie dotyczacym zasady równości wyborów muszą mieścić się w generalnym standardzie wyznaczonym przez ogólna zasadę równości wynikająca z art. 32 ust. 1 Konstytucji, gdyż to ona jest źródłem zasady równości wyborów ${ }^{55}$. Ustawodawca może wprawdzie odstapić od pełnej realizacji zasady równości, w szczególności w jej aspekcie materialnym, ale musi wskazać inne wartości konstytucyjne, którym

49 Z. Jarosz, S. Zawadzki, Wstep do nauki prawa konstytucyjnego, Warszawa 1974, s. 264.

50 S. Gebethner, Wybory..., s. 198.

51 Szerzej zob.: P. Uziębło, Zasada równości wyborów parlamentarnych w państwach europejskich i południowoamerykańskich, Warszawa 2013, s. 17 i n.; T. Kowalczyk, Znaczenie zasady równości prawa wyborczego w prawie polskim przed wejściem w życie Kodeksu wyborczego, „Przegląd Prawa Konstytucyjnego" 2013, nr 2, s. 121 i n.

${ }^{52}$ Zob. np.: S. Gebethner, Wybory..., s. 198; J. Buczkowski, Podstawowe zasady prawa wyborczego III Rzeczypospolitej Polskiej, Lublin 1998, s. 132; P. Uziębło, Zasada..., s. 59 i n.

${ }_{53}$ P. Uziębło, Zasada..., s. 78 i n.; K. Urbaniak, Standardy europejskie zasady równości wyborów a polskie prawo wyborcze i praktyka wyborcza, w: J. Jaskiernia, K. Spryszak (red.), Dwadzieścia lat obowiazywania Konstytucji RP: Polska myśl konstytucyjna a międzynarodowe standardy demokratyczne, Kielce 2017, s. 512.

${ }^{54}$ K. Urbaniak, Standardy..., s. 518.

${ }_{55}$ K. Składkowski, Zasada równości wyborów a wybory do Senatu w kodeksie wyborczym, w: Kodeks wyborczy. Wstęna..., s. 279; K. Urbaniak, Okręg wyborczy a realizacja zasady proporcjonalności i równości wyborów, w: B. Banaszak, A. Bisztyga, A. Feja-Paszkiewicz (red.), Aktualne problemy prawa wyborczego, „Acta Iuridica Lebusana” 1, 2015, s. 435; P. Uziębło, Konstytucyjna zasada równości wyborów a swoboda ksztattowania prawa wyborczego przez ustawodawcę, w: S. Patyra, M. Sadowski, K. Urbaniak (red.), op. cit., s. 244. 
daje pierwszeństwo. Nie można jednak zgodzić się ze stanowiskiem TK, który poddając analizie zasadę równości, stwierdził, że równość materialna wyborów jest dyrektywa, którą ustawodawca powinien starać się realizować, mając świadomość, że nie jest możliwe zrealizowanie jej w pełnym zakresie. Zdaniem Trybunału nie można też uznać, że równość materialna jest koniecznym elementem wyborów demokratycznych. Jej zagwarantowanie możliwe jest tylko w pewnym stopniu i tylko przez odpowiednie skonstruowanie okręgów wyborczych i systemu wyborczego ${ }^{56}$. Trybunał nie przedstawił własnej analizy zasady równości materialnej ani nie odniósł się do meritum problemu, ale odwołał się jedynie do publikowanych w różnym czasie stanowisk doktryny i staną na stanowisku, że „świadome pominięcie przez ustrojodawcę zasady równości materialnej w wyborach do Senatu w art. 97 ust. 2 Konstytucji RP oznacza że również z treści innych przepisów konstytucyjnych zasady tej nie można zrekonstruować". W konkluzji TK stwierdził, że w świetle regulacji konstytucyjnej wybory do Senatu nie muszą realizować zasady równości materialnej57. Wydaje się, że w analizowanym problemie TK zbyt łatwo wyłączył ochronę wynikajacca z zasady równości w aspekcie materialnym. Przyjmując bezkrytycznie stanowisko TK, dopuścilibyśmy daleko idącą dyskryminację wyborców i stworzyli zachętę dla ustawodawcy do stworzeniem przez ustawodawce systemu wyborczego opartego na dyskryminacji wyborców z powodu znacząco słabszego głosu ${ }^{58}$. Takie rozwiąanie z kolei nie realizowałoby postulatu „wyborów fair”, będącego oczywistym elementem zasady dobra wspólnego w odniesieniu do procesu wyborczego.

VI. Przed przystapieniem do analizy stanowienia prawa wyborczego należy wskazać, że niewątpliwym sukcesem w polskim systemie prawa było uchwalenie 5 stycznia 2011 r. ustawy - Kodeks wyborczy ${ }^{59}$. Przyjęto akt prawny rangi kodeksowej, całościowo regulujący problematykę wyborczą ${ }^{60}$. Był to akt niewątpliwie oczekiwany, będący spełnieniem postulatów zgłaszanych od wielu lat w literaturze przedmiotu ${ }^{61}$. Z jego przyjęciem wiązano wiele nadziei,

56 Zob. wyrok TK z 20 lipca 2011 r., K 9/11.

57 Ibidem.

58 K. Urbaniak, Okręg wyborczy..., s. 436-437.

${ }^{59}$ Ustawa z 5 stycznia 2011 r. - Kodeks wyborczy, Dz. U. 2011, Nr 21, poz. 112 ze zm.

60 Zob. W. Skrzydło, Kodyfikacja prawa wyborczego w Polsce - zakres i znaczenie, „Przegląd Prawa Konstytucyjnego" 2011, nr 3; K. Skotnicki (red.), Kodeks wyborczy. Wstepna ocena, Warszawa 2011; M. Chmaj, W. Skrzydło, System wyborczy w Rzeczypospolitej Polskiej, wyd. 4, Warszawa 2011, s. 13-15; K. Eckhardt, Kodeks wyborczy w świetle poglądów doktryny i orzecznictwa Trybunału Konstytucyjnego. Wybrane problemy, „Polityka i Społeczeństwo” 2015, nr 3.

${ }_{61}$ Zob. np. A. Patrzałek, W. Skrzydło, Cele i zasady kodyfikacji prawa wyborczego w Polsce, „Przegląd Sejmowy” 1997, nr 2, s. 10-11; J. Buczkowski, Podstawowe zasady prawa wyborczego III Rzeczypospolitej Polskiej, Lublin 1998, s. 362; K. Skotnicki, Zasada powszechności w prawie wyborczym. Zagadnienia teorii i praktyki, Łódź 2000, s. 84; K. Urbaniak, Wybory europejskie. Projekt ustawy o wyborze członków Parlamentu Europejskiego, „Rzeczpospolita” z 20 sierpnia 2003 r.; A. Żukowski, op. cit., s. 191; J. Jaskóła, Z doświadczén komisarza wyborczego, w: F. Rymarz (red.), Demokratyczne..., s. 110; A. Lubaczewska, Gwarancje realizacji czynnego i biernego prawa wyborczego, w: F. Rymarz (red.), Demokratyczne..., s. 178; W. Skrzydło, O potrzebie $i$ walorach kodyfikacji prawa wyborczego, „Studia Wyborcze” 1, 2006; F. Rymarz, O wyższy poziom legislacji $i$ stabilizację polskiego prawa wyborczego, w: idem (red.), Iudices..., s. 153; K.W. Czaplicki, 
w szczególności związanych z likwidacją sytuacji obowiązywania 5 ustaw wyborczych $^{62}$, przy jednoczesnym odsyłaniu do ordynacji wyborczej do Sejmu i do Senatu, usunięcia rozbieżności między analogicznymi rozwiązaniami w ustawach oraz wprowadzenia nowych rozwiąań prawnych, których potrzeby zgłaszano w doktrynie i praktyce. Liczono także, że przyjęcie aktu rangi kodeksowej spowoduje względną stabilizację prawa wyborczego ${ }^{63}$. Dodać należy, że pomimo krytycznych uwag, które można formułować pod adresem Kodeksu wyborczego, jego uchwalenie odegrało niewątpliwie doniosłą rolę w kształtowaniu polskiego prawa wyborczego ${ }^{64}$.

Wskazujac na standardy tworzenie prawa wyborczego w kontekście stosowania zasady dobra wspólnego, należy zwrócić uwagę na problematykę stabilności prawa wyborczego. Do ustaw wyborczych powinna mieć zastosowanie zasada stabilności prawa, rozumiana jako dokonywanie w nich jedynie takich zmian, które wynikają z nadzwyczajnych okoliczności, związanych np. ze zmianą ustroju państwa, jego organów lub gdy brak takich zmian będzie skutkował zastopowaniem pożądanych przemian politycznych ${ }^{65}$. Dodajmy, że zmiana taka powinna być poprzedzona otwartą i rozciagniętą w czasie debata publiczna. Kazimierz W. Czaplicki wskazuje trzy podstawowe przesłanki uzasadniajace zmianę prawa wyborczego. Według niego „zmiany prawa wyborczego powinny być dokonywane, jeżeli co najmniej:

- zachodzi konieczność wdrożenia nowych instytucji prawnych, w szczególności gwarantujaccych lub pełniej pozwalających realizować podstawowe prawa obywateli,

- dotychczasowe unormowania sa, w świetle praktyki, negatywnie oceniane jako niepełne lub gdy cel, dla których zostały ustanowione, prowadzi do sytuacji społecznie nieaprobowalnej,

- system wyborczy, rozumiany jako sposób kształtowania składu personalnego organów, nie spełnia - w dłuższym przedziale czasowym - swojej funkcji kreacyjnej uniemożliwiającej wyłonienie reprezentatywnej i zdolnej do rządzenia władzy publicznej”66.

Wszystkie przedstawione okoliczności mają charakter nadzwyczajny i sa wyrazem postulatu względnej stabilności prawa wyborczego.

O potrzebie stabilności prawa wyborczego. Wybrane problemy, Toruń 2009, s. 28; B. Michalak, op. cit., s. 166 i n.

${ }^{62}$ Zob. ustawy z: 27 września 1990 r. o wyborze Prezydenta Rzeczypospolitej Polskiej, Dz. U. 2010, Nr 72, poz. 467 ze zm.; 16 lipca 1998 r. - Ordynacja wyborcza do rad gmin, rad powiatów i sejmików województw, Dz. U. 2010, Nr 176, poz. 1190; 12 kwietnia 2001 r. - Ordynacja wyborcza do Sejmu Rzeczypospolitej Polskiej i do Senatu Rzeczypospolitej Polskiej, Dz. U. 2007, Nr 190, poz. 1360 ze zm.; 20 czerwca 2002 r. o bezpośrednim wyborze wójta, burmistrza i prezydenta miasta, Dz. U. 2010, Nr 176, poz. 1191; 23 stycznia 2004 r. - Ordynacja wyborcza do Parlamentu Europejskiego, Dz. U. 2004, Nr 25, poz. 219 ze zm.

${ }^{63}$ K. Skotnicki, Najistotniejsze zmiany w polskim prawie wyborczym $w$ ostatnim ćwierćwie$c z u$, w: W. Hermeliński, B. Tokaj (red.), 25 lat demokratycznego prawa wyborczego i organów wyborczych $w$ Polsce (1991-2016), t. 1, Warszawa 2016, s. 55-56.

${ }^{64}$ Ibidem, s. 57.

${ }^{65}$ K.W. Czaplicki, F. Rymarz, A. Sokala, Aktualne kierunki przemian polskiego i włoskiego prawa wyborczego, w: Z. Witkowski (red.), Konstytucjonalizm wtoski i polski w aktualnych fazach ich przemian, Toruń 2005, s. 167; K.W. Czaplicki, op. cit., s. 5.

${ }^{66}$ K.W. Czaplicki, op. cit., s. 5-6. 
Wagę stabilności prawa wyborczego podkreśla także Komisja Wenecka w wytycznych Kodeksu dobrej praktyki w sprawach wyborczych. Komisja stoi na stanowisku, że „stabilność prawa ma podstawowe znaczenie dla wiarygodności procesu wyborczego, który sam ma żywotne znaczenie dla konsolidacji demokracji. Przepisy, które się często zmieniają - a w szczególności prawo wyborcze - moga dezorientować wyborców. A ponadto wyborcy mogą dojść do wniosku, słusznie lub nie, że prawo wyborcze stanowi po prostu narzędzie w ręku silnych, a ich własne głosy mają mały wpływ na wyniki wyborów"67. Oczywiście największe znaczenie ma nie tyle stabilność podstawowych zasad, gdyż te zwykle nie podlegaja zmianie, ile szczegółowych przepisów dotyczących systemu wyborczego sensu stricto, tj. metod alokacji mandatów, struktury okręgów wyborczych czy wprowadzenia progów zaporowych. Te bowiem przepisy decydują o ostatecznym wyniku wyborów.

Rozważając problematykę stabilności prawa wyborczego, należy zwrócić uwage na dwa aspekty. Pierwszym jest kwestia wejścia w życie przepisów nowelizujących, a drugim częstotliwość wprowadzanych nowelizacji.

Bardzo często zdarza się, że u podłoża zmian prawa wyborczego, przeprowadzanych przed kolejnymi wyborami, leżą intencje związane z doraźnymi celami politycznymi, takimi jak: optymalizacja wyniku wyborczego oraz wyeliminowanie lub osłabienie przeciwników politycznych przez zmiany istotnych elementów systemu wyborczego, w szczególności tych jego elementów, które decydują o wyniku wyborów ${ }^{68}$. Zabiegi takie nazwa się instrumentalizacja prawa wyborczego ${ }^{69}$. Aby ograniczyć możliwość dokonywania zmian prawa wyborczego dyktowanych chęcią uzyskania doraźnej korzyści politycznej, wprowadza się ograniczenia dotyczące możliwości zmian prawa w określonym czasie przed wyborami. Doniosłym orzeczeniem porządkującym demokratyczne standardy tworzenia prawa wyborczego $\mathrm{w}$ tym zakresie w polskim porządku konstytucyjnym był wyrok TK z 3 listopada $2006 \mathrm{rr}^{70}$, który wprowadził zakaz dokonywania zmian w prawie wyborczym w okresie ostatnich sześciu miesięcy przed pierwszą czynnością kalendarza wyborczego. Jeszcze dalej ida zalecenia tzw. Kodeksu dobrych praktyk wyborczych, opracowane przez Komisję Wenecka, które w sytuacji wprowadzania zmian $\mathrm{w}$ prawie wyborczym przed wyborami rekomenduja roczny okres vacatio

\footnotetext{
${ }^{67}$ Kodeks dobrej praktyki w sprawach wyborczych. Wytyczne $i$ wyjaśnienia, Wenecja 2002, s. 29.

${ }^{68}$ Najbardziej ewidentnym przykładem tego typu zabiegów była zmiana w uchwalonej w czerwcu 2001 r. w nowej ordynacji formuły alokacji mandatów z d'Hondta na zmodyfikowaną formułę Sainte-Laguë. Zastosowana inżynieria wyborcza miała na celu osłabienie rozmiaru zwycięstwa wyborczego koalicji Sojuszu Lewicy Demokratycznej-Unii Pracy. Pod rządami nowej regulacji koalicja SLD-UP otrzymała 216 mandatów. Gdyby nie doszło do zmiany formuły alokacji mandatów, koalicja SLD-UP otrzymałaby 245 mandatów i posiadałaby samodzielną większość parlamentarna. Zob. K. Urbaniak, Konstytucyjna zasada..., s. 222-223.

${ }^{69}$ B. Banaszak, Prawo konstytucyjne, wyd. 4, Warszawa 2008, s. 338-339; J. Majchrowski, Instrumentalizacja prawa wyborczego w Polsce, „Ruch Prawniczy, Ekonomiczny i Socjologiczny” 56, 1994, z. 4; J. Buczkowski, op. cit., s. 24; Z. Witkowski, Siedem grzechów głównych polskiej klasy politycznej wobec wyborców, wyborów i prawa wyborczego, Wykład im. prof. dr. Wacława Komarnickiego, Toruń 2015, s. 18 i n.

${ }^{70}$ Wyrok TK z 3 listopada 2006 r., K 31/06.
} 
$\operatorname{legis}^{71}$. Jednak z punktu widzenia realizacji zasady dobra wspólnego i przeprowadzania wyborów z poszanowaniem zasad fair play należy postulować wprowadzenia regulacji, w myśl której zmiany prawa wyborczego dotyczące zasadniczych elementów systemu wyborczego powinny wchodzić w życie od następnej kadencji organu, do którego wyborów dotyczą. Ewentualne wyjątki od tak określonego okresu mogłyby wynikać jedynie z nadzwyczajnych i obiektywnych okoliczności i w żadnym wypadku nie powinny dotyczyć regulacji całokształtu zasad ustalania wyników wyborów.

Zaproponowane rozwiązanie byłoby jak najbardziej wskazane i w efekcie uniemożliwiłoby instrumentalizację prawa wyborczego. Prawo wyborcze decyduje m.in. o kształcie i składzie personalnym wybieralnych organów władzy oraz reguluje zasady dopuszczalnej przez prawo walki politycznej o władzę, w związku z czym nie powinno być tworzone przez bezpośrednio zainteresowanych na podstawie wyznaczników bieżącej sytuacji politycznej.

Drugim problemem, który należy podnieść, jest bardzo duża liczba zmian $\mathrm{w}$ obowiąującym prawie wyborczym ${ }^{72}$. Zasada stabilności prawa wyborczego wskazuje, że ewentualne nowelizacje przepisów regulujaccych przeprowadzanie wyborów powinny mieć charakter nadzwyczajny, najlepiej gdyby były przyjmowane w konsensie najważniejszych sił politycznych i były poprzedzone długim okresem dostosowawczym. Polska rzeczywistość legislacyjna, jeśli chodzi o tworzenie przepisów prawa wyborczego, jest jednak całkowicie odmienna. Dość przypomnieć, że Kodeks wyborczy z 2011 r., z którym wiązano nadzieje na względne ustabilizowanie prawa wyborczego, był jeszcze przed wejściem w życie pięciokrotnie nowelizowany ${ }^{73}$, a do 15 stycznia 2018 r. dokonano w nim w sumie 25 zmian $^{74}$. Oczywiście część z tych zmian miała charak-

${ }^{71}$ Kodeks dobrej praktyki..., s. 10.

${ }^{72}$ Zob. R. Zych, Zmiany w polskim prawie wyborczym z 2015 r., „Przegląd Prawa Konstytucyjnego" 2016, nr 4 .

${ }^{73}$ Ustawy z: 3 lutego 2011 r. o zmianie ustawy - Kodeks wyborczy (Dz. U. 2011, Nr 26, poz. 134); 1 kwietnia 2011 r. o zmianie ustawy - Ordynacja wyborcza do Sejmu Rzeczypospolitej Polskiej i do Senatu Rzeczypospolitej Polskiej oraz ustawy - Kodeks wyborczy (Dz. U. 2011, Nr 94, poz. 550); 15 kwietnia 2011 r. (Dz. U. 2011, Nr 102, poz. 588), która zmieniła także ustawę z 5 stycznia 2011 r. przepisy wprowadzające ustawę - Kodeks wyborczy (Dz. U. 2011, Nr 21, poz. 113); 26 maja 2011 r. o zmianie ustawy o samorządzie gminnym oraz niektórych innych ustaw (Dz. U. 2011, Nr 134, poz. 777); 27 maja 2011 r. o zmianie ustawy - Kodeks wyborczy oraz ustawy - Przepisy wprowadzające ustawę - Kodeks wyborczy (Dz. U. 2011, Nr 147, poz. 881).

${ }^{74}$ Obok nowelizacji wymienionych w przyp. 53, sa to ustawy z: 11 stycznia 2018 r. o zmianach niektórych ustaw w celu zwiększenia udziału obywateli w procesie wybierania, funkcjonowania i kontrolowania niektórych organów publicznych (Dz. U. 2018, poz. 130); 8 grudnia 2017 r. o Służbie Ochrony Państwa (Dz. U. 2018, poz. 138); 9 listopada 2017 r. o zmianie niektórych ustaw w celu poprawy spójności terminologicznej systemu prawnego (Dz. U. 2018, poz. 4); 11 maja 2017 r. o biegłych rewidentach, firmach audytorskich oraz nadzorze publicznym (Dz. U. 2017, poz. 1089); 7 lipca 2016 r. o zmianie ustawy o działach administracji rządowej oraz niektórych innych ustaw (Dz. U. 2016, poz. 1250; a także wyrok TK z 6 kwietnia 2016 r., P 5/14, Dz. U. 2016, poz. 1232); 22 grudnia 2015 r. o zmianie ustawy o działach administracji rządowej oraz niektórych innych ustaw (Dz. U. 2015, poz. 2281); 25 września 2015 r. o zmianie ustawy - Prawo o stowarzyszeniach oraz niektórych innych ustaw (Dz. U. 2015, poz. 1923); 10 lipca 2015 r. o zmianie ustawy - Kodeks wyborczy (Dz. U. 2015, poz. 1044); 25 czerwca 2015 r. o zmianie ustawy - Kodeks wyborczy (Dz. U. 2015, poz. 1043); 25 czerwca 2015 r. o zmianie ustawy o samorządzie gminnym oraz niektórych innych ustaw (Dz. U. 2015, poz. 1045); 11 lipca 2014 r. o zmianie ustawy - Kodeks 
ter obiektywny i związana była z optymalizacją Kodeksu. Przytoczone dane pokazują jednak dużą niestabilność prawa wyborczego. Postulatem de lege ferenda powinno być wprowadzenie zasady, że zmiany prawa wyborczego powinny być inicjowane przez niezależny organ administracji wyborczej, poprzedzone szerokimi konsultacjami społecznymi, a proces legislacyjny powinien być możliwie transparentny i rozłożony w czasie. Spełnienie tych postulatów pozwoliłoby osiagnać pewien stopień pewności co do prawa.

VII. Jak już podniesiono, wybory w państwie demokratycznym, przeprowadzane z poszanowaniem reguł pozwalających uczciwie uwzględnić wolę wyborców są podstawowym sposobem kreowania organów władzy publicznej. Tworzą one jeden z fundamentów państwa czerpiącego swoje podstawy funkcjonowania z woli Narodu. Poddajac analizie podstawowe zasady prawa wyborczego i starając się wskazać na standardy tego prawa wyznaczane przez dobro wspólne, dokonano przeglądu zasad dotyczaccych realizacji praw wyborczych obywateli, instytucjonalnego kształtu systemy wyborczego i procesu wyborczego oraz zasad stanowienia prawa wyborczego. Podsumowując aspekty tworzenia i stosowania prawa wyborczego oraz konstrukcji systemu wyborczego w kontekście realizacji zasady dobra wspólnego, należy stwierdzić, że prawidłowe funkcjonowanie wspartego na Konstytucji pluralistycznego systemu wyborczego oraz stosowanie prawa wyborczego zależą w dużej mierze od uznawania przez wszystkich uczestników tego systemu dobra wspólnego jako takiego i realizowania wskazań z tej zasady wypływających.

dr Krzysztof Urbaniak

Uniwersytet im. Adama Mickiewicza w Poznaniu

krzysztof.urbaniak@amu.edu.pl

\section{ELECTIONS AS A DEMOCRATIC WAY OF CREATING BODIES OF PUBLIC AUTHORITY AND THE COMMON GOOD}

Sum mary

Elections in a democratic state, conducted in compliance with the rules allowing fair consideration to be given to the will of voters, are the primary means of establishing public authorities. They form one of the pillars of a state that derives its foundations from the will of the nation. The article analyses the electoral rights of citizens (i.e. the right to vote and the right to stand as candidates) from the point of view of respect for the principle of the common good. A separate part of

wyborczy oraz niektórych innych ustawy (Dz. U. 2014, poz. 1072); 10 stycznia 2014 r. o zmianie ustawy - Kodeks wyborczy (Dz. U. 2014, poz.179); 10 stycznia 2014 r. o zmianie ustawy - Kodeks wyborczy (Dz. U. 2014, poz. 180); 23 listopada 2012 r. - Prawo pocztowe (Dz. U. 2012, poz. 1529; a także wyrok TK z 18 lipca 2012 r., K 14/12 Dz. U. 2012, poz. 849); 13 lipca 2012 r. o zmianie ustawy o działach administracji rządowej oraz niektórych innych ustaw (Dz. U. 2012, poz. 951); 31 sierpnia 2011 r. o zmianie ustawy - Kodeks wyborczy oraz niektórych innych ustaw (Dz. U. 2011, Nr 217, poz. 1281); 29 lipca 2011 r. o zmianie ustawy o zasadach ewidencji i identyfikacji podatników i płatników oraz niektórych innych ustaw (Dz. U. 2011, Nr 171, poz. 1016; a także wyrok TK z 20 lipca 2011 r., K 9/12, Dz. U. 2011, Nr 149, poz. 889). 
this paper is devoted to reflections on the institutional design of the electoral system and electoral process. The article ends with a part devoted to the issues of creating and applying electoral law, with particular focus on the problem of legal stability. The conducted analysis leads to the conclusion that both, proper functioning of a pluralist electoral system supported by the Constitution and effective application of electoral law depend largely on the recognition of the common good as such by all participants of this system and on the implementation of the indications arising from this principle. 
